\title{
Penerapan Sistem Pendukung Keputusan Penilaian Karyawan Terbaik Dengan Metode Simple Additive Weighting
}

\author{
Ainun Zumarniansyah ${ }^{1}$, Rian Ardianto ${ }^{2}$, Yuris Alkhalifi ${ }^{3}$, Qudsiah Nur Azizah ${ }^{4}$
}

\begin{abstract}
In the Best Employee Rating at PT. Berkah Jaya Motor, there are several factors that are assessed and based on employee performance appraisal in the company. Employee assessment at PT. Berkah Jaya Motor is still experiencing problems because it still uses the Assessment system by way of Negotiations. For work efficiency, the right decision is needed. With the aim to build and provide alternatives. For the best employee assessment using the Simple Additive Weighting (SAW) method. where there are several criteria, each of which has a weight rating so as to provide accurate employee assessment results on each employee's best performance. The final result is obtained from the calculation process, which is the sum of the normalized matrix with weights per criterion that shows the ranking of the best employees from the first to the last of the criteria. From that assessment, it becomes an alternative which then gets the Best Employee.
\end{abstract}

Intisari- Dalam Penilaian Karyawan Terbaik pada PT. Berkah Jaya Motor, ada beberapa faktor yang menjadi penilaian dan berdasarkan penilaian kinerja karyawan diperusahaan. Penilaian karyawan di PT. Berkah Jaya Motor masih mengalami kendala karena masih menggunakan sistem Penilaian dengan cara Perundingan. Demi efisiensi kerja maka pengambilan keputusan yang tepat sangat diperlukan. Dengan tujuan untuk membangun dan memberikan alternatif. Untuk Penilaian karyawan terbaik dengan menggunakan metode Simple Additive Weighting (SAW). dimana ada beberapa kriteria yang masingmasing memiliki bobot penilaian sehingga memberikan hasil penilaian karyawan yang akurat terhadap setiap kinerja karyawan terbaik. Hasil akhir diperoleh dari proses perhitungan, yaitu penjumlahan dari matriks ternormalisasi dengan bobot per kriteria yang menunjukan rangking pemilihan karyawan terbaik dari pertama hingga yang terakhir dari kriteria. Dari penilaian tersebutlah menjadi alternatif yang kemudian mendapat Karyawan Terbaik.

Kata Kunci-Sistem Pendukung Keputusan, Karyawan Terbaik, Simple Additive Weighting

\section{PENDAHULUAN}

Penilaian terhadap karyawan dengan cara memilih karyawan terbaik. Hal ini dimaksud untuk meningkatkan semangat kerja karyawan. Akan tetapi penilaian yang dilakukan pada PT. Berkah Jaya Motor masih bersifat subjektif sehingga pada proses Penilaian karyawan terbaik menjadi belum akurat.

1,2,3 Program Studi Sistem Informasi, Universitas Bina Sarana Informatika, Jl. Kramat Raya No.98, RT.2/RW.9, Kwitang, Kec. Senen, Kota Jakarta Pusat, Daerah Khusus Ibukota Jakarta 10450 (Telp: (021)8000063; e-mail: ainun.azm@bsi.ac.id, rian.rao@bsi.ac.id,yuris.yak@bsi.ac.id,qudsiah.qna@bsi.ac.id
Hal ini yang menjadikan perlunya sebuah perhitungan yang mampu mengelola data penilaian karyawan terbaik dan menghasilkan rangking dari hasil perhitungan bobot nilai karyawan.

Dalam menciptakan karyawan yang terampil dan mampu memberikan kontribusi terhadap keberhasilan perusahaan perlu adanya penilaian prestasi kerja atas segala bentuk pekerjaan yang telah dilaksanakan oleh karyawan tersebut. Penilaian kinerja harus dilakukan secara adil, valid dan relevan dengan pekerjaan yang dikerjakan, selain itu harus bebas dari diskriminasi[1] .

Masalah yang muncul dapat berskala besar atau kecil yang sangat berpengaruh dalam hasil keputusan. Sekarang ini manusia mulai mengembangkan sistem yang dapat membantu menentukan alternatif terbaik dalam suatu permasalahan, yaitu sistem pendukung keputusan (SPK). Di dalam sistem pendukung keputusan terdapat alternatif, kriteria dan bobot yang digunakan untuk menentukan suatu solusi[2].

Oleh karena itu diperlukan sebuah metode yang mampu menyelesaikan pengambilan keputusan Penilaian Karyawan terbaik dengan banyak kriteria (multikriteria) dan memerlukan waktu pemrosesan yang relatif cepat. Salah satu solusi dengan penerapan teknologi informasi dalam pengambilan keputusan adalah penggunaan Sistem Pendukung Keputusan (SPK). Penerapan SPK dalam dalam pengambilan keputusan terhadap suatu masalah bisa dilakukan dengan cepat. SPK memiliki beberapa metode, dalam penelitian ini penulis menggunakan metode SAW (Simple Additive Weighting), sebagai pembobotan kriteria sekaligus perangkingan. Konsep dasar dari metode SAW adalah mencari penjumlahan terbobot dari rating kinerja setiap alternatif pada semua atribut. Metode SAW bisa digunakan untuk pendukung pengambilan suatu keputusan dengan menghasilkan nilai.

Sistem adalah Sekumpulan Prosedur yang saling berkaitan dan saling tersambung untuk melakukan suatu tugas bersama. Secara garis besar, sebuah sistem informasi terdiri atas tiga komponen utama. Ketiga komponen tersebut mencakup software, hardware, dan brainware ketiga komponen ini saling tersambung satu sama lain[3].

Sistem Pendukung Keputusan adalah adalah suatu sistem informasi yang menggunakan model-model keputusan, basis data, dan pemikiran manajer sendiri atau Decision Support System (DSS) adalah sebuah sistem yang mampu memberikan kemampuan pemecahan masalah maupun kemampuan pengkomunikasian untuk masalah dengan kondisi semi terstruktur dan tak terstruktur[4]. Sistem Pendukung keputsan sistem berbasis komputer yang terdiri dari beberapa kompulan, dan yang satu dengan yang lainnya saling berhubungan[5]. 
Keputusan merupakan poses pencarian masalah yang berawal dari latar belakang, Indentifikasi Masalah hingga kepada terbentuknya kesimpulan atau rekomendasi[6]. Untuk pengambilan keputusan yang akurat perlu adanya pendukung keputusan. Tujuannya untuk dapat menjadi pemecahan masalah yang terjadi pada sistem sebelumnya, sehingga hasil yang diperoleh menjadi tepat.

Karyawan adalah seseorang yang ditugaskan sebagai pekerja dari sebuah perusahaan untuk melakukan operasional pada perusahaan. Kedudukan karyawan dalam sebuah perusahaan sangatlah penting, oleh karena itu pengelolaan karyawan cukup penting karena akan mempengaruhi banyak aspek penentu keberhasilan kinerja perusahaan. Karyawan tentu erat kaitannya dengan kinerja, oleh karena itu, proses penilaian karyawan dirasa perlu dilakukan dalam suatu perusahaan, terutama dalam penentuan karyawan terbaik guna memberi motivasi[2].

Penelitian sebelumnya dilakukan penelitian untuk menentukan karyawan kontrak menjadi karyawan tetap pada PT. Gowa Motor Group menggunakan metode Techinique for Order Preference by Similarity to Ideal Solution (TOPSIS). Kriteria yang digunakan untuk menentukan pada penelitian ini adalah sebanyak 5 kriteria antara lain kinerja, kedisiplinan, loyalitas, pengalaman bekerja dan tingkat pendidikan. Kemudian dirancang sebuah aplikasi berbasis dekstop dengan menggunakan bahasa pemrograman Java dan basis data MySQL menggunakan aplikasi XAMPP[7].

Penelitian selanjutnya dilakukan penelitian untuk menentukan karyawan berprestasi pada PT. Capella Dinamik Nusantara Takengon dengan metode Analytical Hierarchy Process (AHP). Kriteria yang digunakan untuk menentukan pada penelitian ini adalah sebanyak 4 kriteria antara lain kejujuran, kedisiplinan, rajin dan tanggungjawab. Hasil dari penelitian ini adalah dapat membantu perusahaan dalam memilih karyawan berprestasi yang tepat guna dijadikan bahan pertimbangan dalam proses pemilihan karyawan berprestasi di perusahaan[8].

Penelitian selanjutnya dilakukan penelitian untuk evaluasi kinerja karyawan dengan metode Logika Fuzzy Tahani Kriteria yang digunakan untuk menentukan pada penelitian ini adalah sebanyak 6 kriteria antara lain kehadiran, kualitas kerja, kreatifitas, technical skills, communication skills dan attitude, Hasil dari penelitian ini adalah dengan logika fuzzy model Tahani proses evalusi kinerja karyawan yang dilakukan penilaian menjadi lebih adil dan akurat dengan memperhatikan nilai yang proporsional bagi setiap kriteria yang digunakan[9].

Adapun topik bahasan pada penelitian ini yakni melakukan penelitian untuk memilih karyawan terbaik pada PT Berkah Jaya Motor menggunakan sistem penunjang keputusan dengan metode Simple Additive Weighting (SAW). Kriteria yang akan digunakan pada penelitian ini berjumlah 4 kriteria yakni kehadiran, loyalitas, kinerja dan kedisiplinan. Dengan harapan dapat membantu perusahaan untuk menentukan karyawan terbaik pada perusahaannya.

\section{METODE PENELITIAN}

\section{A. Tahapan Penelitian}

Proses penelitian merupakan kegiatan untuk memperoleh atau mendapatkan suatu pengetahuan atau memecahkan suatu permasalahan yang dihadapi, yang dilakukan secara ilmiah, sistematis, dan logis. Dalam proses suatu penelitian, maka tahap-tahap penelitian tentu tidak terlepas dari suatu penelitian itu sendiri. Berikut adalah tahap dalam pelaksaan penelitian yang di tempuh:

\section{1) Survey Litelatur}

Dalam Tahap ini, peneliti melakukan pegumpulan berupa bahan literatur terkait informasi.

\section{2) Identifikasi Masalah}

Melakukan penelitian dengan cara melakukan identifikasi tentang masalah yang akan dibahas, Berkaitan dengan sistem pendukung keputusan karyawan terbaik pada PT Berkah Jaya Motor menggunakan metode Simple Additive Weighting (SAW) Berdasarkan infromasi yang diperoleh.

\section{3) Studi Pustaka}

Penulis mempelajari literatur berupa buku teori tentang sistem pendukung keputusan dan SAW yang akan digunakan sebagai kajian teori dalam penelitian.

Metode SAW sering juga dikenal istilah metode penjumlahan terbobot. Konsep dasar metode SAW adalah mencari penjumlahan terbobot dari rating kinerja pada setiap alternatif pada semua atribut. Metode SAW membutuhkan proses normalisasi matriks keputusan (X) ke suatu skala yang dapat diperbandingkan dengan semua rating alternatif yang ada. Formula untuk melakukan normalisasi tersebut adalah:

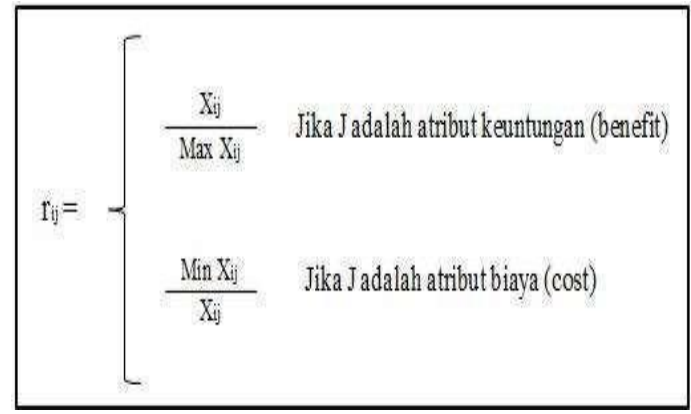

Sumber : [10]

Gbr 1. Normalisasi Metode SAW

Keterangan:

a. Max Xij= Nilai terbesar dari setiap kriteria.

b. Min Xij= Nilai terkecil dari setiap kriteria.

c. $\mathrm{Xij}=$ Nilai atribut yang dimiliki dari setiap kriteria.

d. Benefit = Jika Nilai terbesar adalah terbaik.

b. Cost $=$ Jika nilai terkecil adalah terbaik

dimana rij adalah rating kinerja ternormalisasi dari alternatif $\mathrm{Ai}$ pada atribut $\mathrm{Cj} ; \mathrm{i}=1,2, \ldots, \mathrm{m}$ dan $\mathrm{j}=1,2, \ldots, \mathrm{n}$. 
$n$

$V \vec{i}=\Sigma \boldsymbol{W j} r j$

$$
j=1
$$

Nilai preferensi untuk setiap alternatif (Vi) diberikan sebagai berikut:

a. $\quad V i=$ Rangking untuk setiap alternatif

b. $\mathrm{Wj}=$ Nilai Bobot Rangking (Setiap kriteria)

c. Rij = Nilai Rating kinerja Ternomalisasi

Keunggulan dari metode Simple Additive Weighting dibandingkan dari metode sistem keputusan yang lain terletak pada kemampuannya dalam melakukan penilaian secara lebih tepat karena didasarkan pada nilai kriteria dan bobot tingkat kepentingan yang dibutuhkan. Langkah penyeleksian metode Simple Additive Weighting sebagai berikut:

a. Menentukan Kriteria - kriteria yang akan dijadikan acuan dalam pengambilan keputusan yaitu $\mathrm{Ci}$

b. Menentukan Rating kecocokan setiap alternatif

c. Membuat matriks keputusan berdasarkan kriteria (Ci), kemudian melakukan normalisasi matriks berdasarkan persamaan yang disesuaikan dengan jenis atribut (atribut keuntungan ataupun atribut biaya) sehingga diperoleh matriks ternormalisasi R.

d. Hasil akhir diperoleh dari proses perangkingan yaitu penjumlahan dari perkalian matriks ternormalisasi $\mathrm{R}$ dengan vektor bobot sehingga diperoleh nilai terbesar yang dipilih sebagai alternatif terbaik (Ai) sebagai solusi.

4) Hipotesis

Penulis memiliki hipotesis awal, yaitu:

Ho $=$ Tidak ada pengaruh signifikan Kehadiran, Loyalitas, Kinerja, Kedisiplinan dan Komunikasi Dalam memilih Karyawan Terbaik.

$\mathrm{H} 1=$ Ada pengaruh signifikan Kehadiran, Loyalitas, Kinerja, Kedisiplinan dan Komunikasi Dalam memilih Karyawan Terbaik Menentukan Variabel dan Sumber Data.

Penulis menentukan variabel dari sistem pendukung keputusan pemilihan karyawan terbaik menggunakan metode Simple Additive Weighting (SAW) dari Kehadiran, Loyalitas, Kinerja, Kedisiplinan dan Komunikasi, Kemudian menentukan subjek penelitian.

\section{5) Obsevasi langsung dan perizinan}

Penulis datang langsung ke PT Berkah Jaya Motor dan meminta perizinan kepada pihak terkait dan berwenang dalam bagian pemilihan karyawan terbaik.

\section{6) Mengumpulkan Data}

Penulis menanyakan apa saja Nilai dan kriteria untuk pemilihan karyawan terbaik untuk dijadikan data yang dibutuhkan dalam membuat statistik Simple Additive Weighting.
7) Analisis Data

Penulis menganalisa dan mengolah data dari informasi yang didapat dengan menggunakan skala.

8) Menarik Kesimpulan

Peneliti menarik sebuah kesimpulan berdasarkan analisis pada bab-bab sebelumnya dan diperiksa apakah kesimpulan sesuai dengan hipotesis, maksud dan tujuan peneliti. Selain memberikan saran yang dapat digunakan sebagai masukan bagi perusahaan terkait untuk dimanfaatkan lebih lanjut.

B. Metode Pengumpulan Data

1) Dalam penelitian ini, metode pengumpulan data yang dilakukan ialah menggunakan metode observasi, mengunjungi tempat yang berkaitan, wawancara, menyebarkan kuesioner yang telah disiapkan serta mengumpulkan data dengan metode literatur atau studi pustaka yang berhubungan dengan topik pembahasan.

2) Populasi dan Sampel

Populasi ialah Populasi keseluruhan elemen atau unsur yang akan diteliti[11]. Sedangkan sampel jika tidak ada populasi Idealnya agar hasil penelitiannya lebih bisa dipercaya [12]. Berikut ini adalah sample yang digunakan untuk penelitian:

Tabel 1.

Sample Karyawan

\begin{tabular}{ccl}
\hline No. & $\begin{array}{c}\text { Kode } \\
\text { Karyawan }\end{array}$ & \multicolumn{1}{c}{ Nama } \\
\hline 1. & A1 & Yunita Amelia \\
\hline 2. & A2 & Muhammad Fahmi \\
\hline 3. & A3 & Jimmi Mulyana \\
\hline 4. & A4 & Muhammad Ilham \\
\hline 5. & A5 & Andin aulia \\
\hline 6. & A6 & Bella Putri \\
\hline 7. & A7 & Saputra \\
\hline 8. & A8 & Ikhsan Febrian \\
\hline 9. & A9 & Ali Purnama \\
\hline 10. & A10 & Rizki Ferdiansyah \\
\hline
\end{tabular}

\section{Metode Analisis Data}

Analisis merupakan bagian penting dalam metodelogi penelitian. Dikarenakan dengan melakukan analisis data tersebut dapat diberi arti dan makna yang berguna dalam suatu penyelesaian masalah. Metode Simple Additive Weighting (SAW) merupakan metode pengambilan keputusan yang komprehensif. Teknik analisis data yang digunakan adalah Analisis kualitatif dan kuantitatif.

\section{HASIL DAN PEMBAHASAN}

A. Tahapan Penentuan Kriteria dan Bobot

Langkah pertama dalam penyelesaian metode Simple Additive Weighting (SAW) yaitu mendefinisikan terlebih dahulu kriteria - kriteria yang akan dijadikan sebagai tolak ukur 
penyelesaian masalah[13]. Kriteria dan bobot yang dijadikan acuan perhtunga karyawan terbaik, dijabarkan dengan tabel berikut :

Tabel 2.

Kriteria pemilihan karyawan Terbaik

\begin{tabular}{clcc}
\hline Kode & Kriteria & Range $(\%)$ & Bobot \\
\hline C1 & Kehadiran & $30 \%$ & 0,3 \\
\hline C2 & Loyalitas & $20 \%$ & 0,2 \\
\hline C3 & Kinerja & $20 \%$ & 0.2 \\
\hline C4 & Kedisiplinan & $15 \%$ & 0,15 \\
\hline
\end{tabular}

1) Kriteria Kehadiran

Kriteria kehadiran merupakan persyaratan yang dibutuhkan dalam pemilihan karyawan tebaik, berdasarkan kriteria yang telah diberikan oleh perusahaan.

Tabel 3.

Kriteria Kehadiran

\begin{tabular}{ccc}
\hline Kehadiran & Skala & Bobot \\
\hline 50 & Sangat Tidak Setuju & 1 \\
\hline $60-69$ & Tidak Setuju & 2 \\
\hline $70-79$ & Netral & 3 \\
\hline $80-89$ & Setuju & 4 \\
\hline $90-100$ & Sangat Setuju & 5 \\
\hline
\end{tabular}

2) Kriteria Loyalitas

Kriteria Loyalitas merupakan persyaratan yang dibutuhkan dalam pemilihan karyawan terbaik, berdasarkan kriteria yang telah diberikan oleh perusahaan.

Tabel 4.

Kriteria Loyalitas

\begin{tabular}{ccc}
\hline Loyalitas & Skala & Bobot \\
\hline 50 & $\begin{array}{c}\text { Sangat Tidak } \\
\text { Setuju }\end{array}$ & 1 \\
\hline $60-69$ & Tidak Setuju & 2 \\
\hline $70-79$ & Netral & 3 \\
\hline $80-89$ & Setuju & 4 \\
\hline $90-100$ & Sangat Setuju & 5 \\
\hline
\end{tabular}

3) Kriteria Kinerja

Kriteria Kinerja merupakan persyaratan yang dibutuhkan dalam pemilihan karyawan terbaik, berdasarkan kriteria yang telah diberikan oleh perusahaan.

Tabel 5.

Kriteria Kinerja

\begin{tabular}{ccc}
\hline Kinerja & Skala & Bobot \\
\hline 50 & Sangat Tidak Setuju & 1 \\
\hline $60-69$ & Tidak Setuju & 2 \\
\hline $70-79$ & Netral & 3 \\
\hline $80-89$ & Setuju & 4 \\
\hline $90-100$ & Sangat Setuju & 5 \\
\hline
\end{tabular}

4) Kriteria Kedisiplinan

Kriteria Kedisiplinan merupakan persyaratan yang dibutuhkan dalam pemilihan karyawan terbaik, berdasarkan kriteria yang telah diberikan oleh perusahaan.

Tabel 6.

Kriteria Kedisiplinan

\begin{tabular}{ccc}
\hline Kedisiplinan & Skala & Bobot \\
\hline 50 & Sangat Tidak Setuju & 1 \\
\hline $60-69$ & Tidak Setuju & 2 \\
\hline $70-79$ & Netral & 3 \\
\hline $80-89$ & Setuju & 4 \\
\hline $90-100$ & Sangat Setuju & 5 \\
\hline
\end{tabular}

Dalam pemilihan Karyawan terbaik dengan metode Simple Additive Weighting (SAW) berdasarkan kriteria-kriteria diatas maka diperoleh data sebagai berikut:

Tabel 8.

Data Karyawan

\begin{tabular}{clcccc}
\hline \multirow{2}{*}{ No } & \multicolumn{1}{c}{ Nama } & \multicolumn{4}{c}{ Kriteria } \\
\cline { 2 - 6 } & C1 & C2 & C3 & C4 \\
\hline 1. & Yunita Amelia & 4 & 3 & 4 & 5 \\
\hline 2. & $\begin{array}{l}\text { Muhammad } \\
\text { Fahmi }\end{array}$ & 4 & 4 & 3 & 4 \\
\hline 3. & Jimmi Mulyana & 4 & 4 & 4 & 4 \\
\hline 4. & Muhammad Ilham & 3 & 4 & 4 & 4 \\
\hline 5. & Andin aulia & 4 & 4 & 3 & 4 \\
\hline 6. & Bella Putri & 4 & 4 & 4 & 4 \\
\hline 7. & Saputra & 5 & 5 & 5 & 4 \\
\hline 8. & Ikhsan Febrian & 4 & 5 & 5 & 4 \\
\hline 9. & Ali Purnama & 4 & 5 & 5 & 4 \\
\hline 10. & Rizki Ferdiansyah & 5 & 5 & 4 & 4 \\
\hline
\end{tabular}

B. Rating Kecocokan Alternatif

Dalam penentuan rating kecocokan maka nilai dari masingmasing kriteria kemudian dimasukkan kedalam tabel rating kecocokan yang telah disesuaikan dengan nilai dari tabel kriteria. Maka tabel rating kecocokan sebagai berikut:

Tabel 9.

Rating Kecocokan

\begin{tabular}{ccccc}
\hline Nama & C1 & C2 & C3 & C4 \\
\hline A1 & 88,33 & 73,33 & 86,67 & 90,00 \\
\hline A2 & 88,33 & 86,67 & 76,67 & 80,00 \\
\hline A3 & 88,33 & 88,33 & 83,33 & 81,67 \\
\hline A4 & 78,33 & 86,67 & 81,67 & 86,67 \\
\hline A5 & 86,67 & 83,33 & 76,67 & 81,67 \\
\hline A6 & 88,33 & 85,00 & 85,00 & 88,33 \\
\hline A7 & 91,67 & 90,00 & 90,00 & 88,33 \\
\hline A8 & 88,33 & 95,00 & 91,67 & 88,33 \\
\hline A9 & 88,33 & 95,00 & 95,00 & 88,33 \\
\hline A10 & 95,00 & 95,00 & 85,00 & 88,33 \\
\hline
\end{tabular}




\section{JURNAL SISTEM}

\section{INFORMASI STMIK ANTAR}

$\mathbf{X}=\quad \begin{aligned} & 4 \\ & 4 \\ & 4 \\ & 3 \\ & 4 \\ & 4 \\ & 5 \\ & 4 \\ & 4 \\ & 5\end{aligned}$

C. Normalisasi Matriks

Membuat normalisasi matriks berdasarkan persamaan yang disesuaikan dengan jenis atribut (atribut keuntungan maupun atribut biaya) sehingga diperoleh matriks ternomalisasi $\mathrm{R}$ sebagai berikut:

Untuk atribut benefit

Rij=

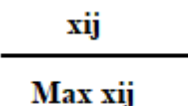

1) Normalisasi Untuk Kehadiran

$\mathrm{R}_{11}=0,8$

$\mathrm{R}_{12}=0,8$

$\mathrm{R}_{13}=0,8$

$\mathrm{R}_{14}=0,6$

$\mathrm{R}_{15}=0,8$

$\mathrm{R}_{16}=0,8$

$\mathrm{R}_{17}=1,0$

$\mathrm{R}_{18}=0,8$

$\mathrm{R}_{19}=0,8$

$\mathrm{R}_{110}=1,0$

2) Normalisasi Untuk Loyalitas

$\mathrm{R}_{21}=0,6$

$\mathrm{R}_{22}=0,8$

$\mathrm{R}_{23}=0,8$

$\mathrm{R}_{24}=0,8$

$\mathrm{R}_{25}=0,8$

$\mathrm{R}_{26}=0,8$

$\mathrm{R}_{27}=1,0$

$\mathrm{R}_{28}=1,0$

$\mathrm{R}_{29}=1,0$

$\mathrm{R}_{210}=1,0$

3) Normalisasi Untuk Kinerja

$\mathrm{R}_{31}=0,8$

$\mathrm{R}_{32}=0,6$

$\mathrm{R}_{33}=0,8$

$\mathrm{R}_{34}=0,8$

$\mathrm{R}_{35}=0,6$

$\mathrm{R}_{36}=0,8$

$\mathrm{R}_{37}=1,0$
Untuk atribut cost

Rij $=$ Min xij
$\mathrm{R}_{38}=1,0$

$\mathrm{R}_{39}=1,0$

$\mathrm{R}_{310}=0,8$

4) Normalisasi Untuk Kedisiplinan

$\mathrm{R}_{41}=1,0$

$\mathrm{R}_{42}=0,8$

$\mathrm{R}_{43}=0,8$

$\mathrm{R}_{44}=0,8$

$\mathrm{R}_{45}=0,8$

$\mathrm{R}_{46}=0,8$

$\mathrm{R}_{47}=0,8$

$\mathrm{R}_{48}=0,8$

$\mathrm{R}_{49}=0,8$

$\mathrm{R}_{410}=0,8$

$\mathbf{R}=\left(\begin{array}{llll}0,8 & 0,6 & 0,8 & 1,0 \\ 0,8 & 0,8 & 0,6 & 0,8 \\ 0,8 & 0,8 & 0,8 & 0,8 \\ 0,6 & 0,8 & 0,8 & 0,8 \\ 0,8 & 0,8 & 0,6 & 0,8 \\ 0,8 & 0,8 & 0,8 & 0,8 \\ 1,0 & 1,0 & 1,0 & 0,8 \\ 0,8 & 1,0 & 1,0 & 0,8 \\ 0,8 & 1,0 & 1,0 & 0,8 \\ 1,0 & 1,0 & 0,8 & 0,8\end{array}\right)$

D. Melakukan Proses Perangkingan

Untuk mencari nilai dari masing-masing karyawan yang dijadikan sebagai karyawan terbaik dala menentukan rangking dengan menggunakan rumus sebagai berikut:

$\mathrm{V} 1=(0,8 * 0,30)+(0,6 * 0,20)+(0,8 * 0,20)+(1,0 * 0,15)$

$=0,24+0,12+0.16+0.15$

$=0,67$

$\mathrm{V} 2=(0,8 * 0,30)+(0,8 * 0,20)+(0,6 * 0,20)+(0,8 * 0,15)$

$=0,24+0,16+0.12+0,12$

$=0,64$

$\mathrm{V} 3=(0,8 * 0,30)+(0,8 * 0,20)+(0,8 * 0,20)+(0,8 * 0,15)$

$=0,24+0,16+0,16+0,12$

$=0,68$

$\mathrm{V} 4=(0,6 * 0,30)+(0,8 * 0,20)+(0,8 * 0,20)+(0,8 * 0,15)$

$=0,18+0,16+0,16+0,12$

$=0,62$

V5 $=(0,8 * 0,30)+(0,8 * 0,20)+(0,6 * 0,20)+(0,8 * 0,15)$

$=0,24+0,16+0,12+0,12$

$=0,64$

V6 $=(0,8 * 0,30)+(0,8 * 0,20)+(0,8 * 0,20)+(0,8 * 0,15)$

$=0,24+0,16+0,16+0,12$

$=0,68$

$\mathrm{V} 7=(1,0 * 0,30)+(1,0 * 0,20)+(1,0 * 0,20)+(0,8 * 0,15)$

$=0,3+0,2+0,2+0,12$

$=0,82$

$\mathrm{V} 8=(0,8 * 0,30)+(1,0 * 0,20)+(1,0 * 0,20)+(0,8 * 0,15)$

$=0,24+0,2+0,2+0,12$

$=0,76$ 


$$
\begin{aligned}
\mathrm{V} 9 & =(0,8 * 0,30)+(1,0 * 0,20)+(1,0 * 0,20)+(0,8 * 0,15) \\
& =0,24+0,2+0,2+0,12 \\
& =0,76 \\
\mathrm{~V} 10 & =(1,0 * 0,30)+(1,0 * 0,20)+(0,8 * 0,20)+(0,8 * 0,15) \\
& =0,3+0,2+0,16+0,12 \\
& =0,78
\end{aligned}
$$

Hasil dari Perhitungan di atas dapat disimpulkan hasil dengan perangkingan nilai V1 dari nilai Terbesar dan Terkecil, Sehingga di dapat alternatif terbaik pemilihan karyawan terbaik berdasarkan nilai tertinggi terdapat pada tabel berikut ini :

Tabel 10.

Penentuan Rangking

\begin{tabular}{cccc}
\hline No & Nama & Nilai & Presentase \\
\hline 1. & Saputra & 0,82 & $82 \%$ \\
\hline 2. & Rizki Ferdiansyah & 0,78 & $78 \%$ \\
\hline 3. & Ikhsan Febrian & 0,76 & $76 \%$ \\
\hline 4. & Ali Purnama & 0,76 & $76 \%$ \\
\hline 5. & Bella Putri & 0,68 & $68 \%$ \\
\hline 6. & Jimmi Mulyana & 0,68 & $68 \%$ \\
\hline 7. & Yunita Amelia & 0,67 & $67 \%$ \\
\hline 8. & Muhammad Fahmi & 0,64 & $64 \%$ \\
\hline 9 & Andin Aulia & 0,64 & $64 \%$ \\
\hline 10. & $\begin{array}{c}\text { Muhammad } \\
\text { Ilham }\end{array}$ & 0,62 & $62 \%$ \\
\hline \multicolumn{4}{c}{}
\end{tabular}

Pada tabel 10 diatas, setelah dilakukan perhitungan menggunakan metode SAW, Diketahui bahwa nilai tertinggi ialah 0,82 atau $82 \%$ sebagai peringkat 1 atas nama Saputra, sedangkan untuk total nilai terendah ialah 0,62 atau $62 \%$ sebagai peringkat terkecil atas nama Andin Aulia dan Muhammad Ilham.

\section{KESIMPULAN}

Kesimpulan yang dapat diambil dari hasil penelitian dan dari semua proses yang telah dilakukan sebagai berikut:

1) Dalam penelitian ini penulis menggunakan metode Simple Additive Weighting (SAW) dan terdapat lima kriteria utama yang digunakan dalam pemilihan karyawan terbaik ini, yaitu Kehadiran, Loyaitas, Kinerja, Kedisiplinan dan Komunikasi. Dimana dapat disimpulkan bahwa Kehadiran menjadi kriteria tertinggi pada pemilihan karyawan terbaik.

2) Diharapkan kepada para karyawan PT Berkah Jaya Motor. untuk dapat meningkatkan kinerjanya dalam bekerja agar mendapatkan penilaian kerja yang baik dari pihak perusahaan.

3) Pada penelitian ini d alam proses pemilihan karyawan terbaik terdapat Sepuluh kandidat dan pada hasil akhirnya yang terpilih sebagai karyawan terbaik pada PT Berkah Jaya Motor yaitu Saputra dengan presentase $82 \%$ atau sebesar 0,82 .

\section{UCAPAN TERIMA KASIH}

Terimakasih banyak kami ucapkan kepada PT Berkah Jaya Motor yang sudah memberikan kesempatan untuk dilakukan penelitian sehingga paper penelitian ini berhasil disusun.

\section{REFERENSI}

[1] A. G. Anto, H. Mustafidah, and A. Suyadi, "Sistem Pendukung Keputusan Penilaian Kinerja Karyawan Menggunakan Metode SAW (Simple Additive Weighting) di Universitas Muhammadiyah Purwokerto," JUITA, vol. 4, pp. 193-200, 2015, Accessed: Jun. 18, 2021. [Online]. Available: http://www.jurnalnasional.ump.ac.id/index.php/JUITA/article/v iew/876

[2] A. T. Widiyanto and Y. Erliani, "Sistem Pendukung Keputusan Dalam Menentukan Karyawan Terbaik Pada PTt. Tembaga Mulia Semanan Dengan Metode Topsis,” 2016.

[3] I. Pratama, Sistem Informasi dan Implementasinya. 2019.

[4] D. I. Sabanayo, "Sistem Pendukung Keputusan Pemilihan Karyawan Terbaik Menggunakan Metode SAW Pada PT. Berkah Cahaya Muria Kudus," 2015.

[5] T. Syahputra, M. Yetri, and S. D. Armaya, "Sistem Pengambilan Keputusan Dalam Menentukan Kualitas Pemasukan Pangan Segar Metode Smart," JURTEKSI, vol. 04, no. 01, 2017, Accessed: Jun. 18, 2021. [Online]. Available: https://jurnal.stmikroyal.ac.id/index.php/jurteksi/article/view/19 $/ 18$

[6] I. Fahmi, Teori dan Teknik Pengambilan Keputusan Kualitatif dan Kuantitatif . 2016.

[7] S. Mallu, "Sistem Pendukung Keputusan Penentuan Karyawan Kontrak Menjadi Karyawan Tetap Menggunakan Metode TOPSIS," JITTER, vol. 01, no. 02, 2015, Accessed: Jun. 18, 2021. [Online]. Available: http://journal.widyatama.ac.id/index.php/jitter/article/view/53

[8] K. Safitri, F. Tinus Waruwu, and Mesran, "Sistem Pendukung Keputusan Pemilihan Karyawan Berprestasi Dengan Menggunakan Metode Analytical Hieararchy Process (Studi Kasus : PT.Capella Dinamik Nusantara Takengon)," vol. 1, no. 1, pp. 12-16, 2017, Accessed: Jun. 18, 2021. [Online]. Available: https://ejurnal.stmik-

budidarma.ac.id/index.php/mib/article/view/317/268

[9] G. Taufiq, "Implementasi Logika Fuzzy Tahani Untuk Model Sistem Pendukung Keputusan Evaluasi Kinerja Karyawan," Jurnal Pilar Nusa Mandiri, vol. XII, no. 1, 2016, Accessed: Jun. 18, 2021. [Online]. Available: http://ejournal.nusamandiri.ac.id/index.php/pilar/article/view/2 $54 / 224$

[10] D. Nofriansyah, Konsep Data Mining Vs Sistem Pendukung Keputusan, I. Yogyakarta: Deepublish, 2014.

[11] D. Fatihudin, Metode Penelitian untuk Ekonomi, Manajemen dan Akuntansi. 2015.

[12] J. Hartono, Analisis \& Desain Sistem Informasi Pendekatan Terstruktur Teori Dan Praktik Aplikasi Bisnis. 2014.

[13] I. G. B. Subawa, I. M. A. Wirawan, and I. M. G. Sunarya, "Pengembangan Sistem Pendukung Keputusan Pemilihan Pegawai Terbaik Menggunakan Metode Simple Additive Weighting (SAW) Di PT Tirta Jaya Abadi Singaraja," Karmapati, vol. 4, no. 5, 2015, Accessed: Jun. 18, 2021. [Online]. Available:

https://ejournal.undiksha.ac.id/index.php/KP/article/view/6623/ 4511 


\section{JURNAL SISTEM}

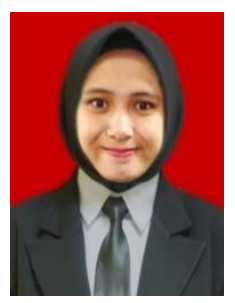

Ainun Zumarniansyah. Lahir di Bekasi, pada tanggal 22 Juli 1997. Tahun 2019 lulus Program Sarjana Strata Satu (S1) Jurusan Sistem Informasi di STMIK Nusa Mandiri Jakarta.

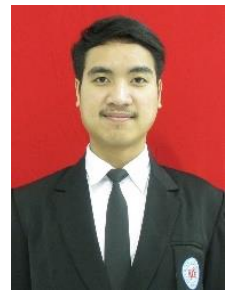

Rian Ardianto. Lahir di Tasikmalaya, pada tanggal 23 Februari 1998. Tahun 2019 lulus Program Sarjana Strata Satu (S1) Jurusan Sistem Informasi di Universitas BSI Bandung.

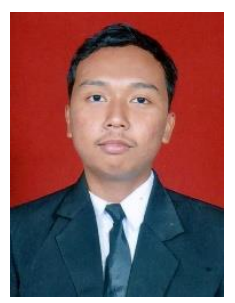

Yuris Alkhalifi. Lahir di Karawang, pada tanggal 21 April 1997. Tahun 2019 lulus Program Sarjana Strata Satu (S1) Jurusan Sistem Informasi di STMIK Nusa Mandiri Jakarta.

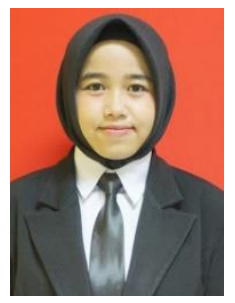

Qudsiah Nur Azizah. Lahir di Banyumas, pada tanggal 28 September 1997. Tahun 2019 lulus Program Sarjana Strata Satu (S1) Jurusan Sistem Informasi di Universitas BSI Bandung. 